\title{
METODE PEMBELAJARAN BERBASIS GAME UNTUK MENINGKATKAN KETRAMPILAN MEMBACA DAN MENULIS AKSARA JAWA
}

\author{
Whinny Qori Fatima ${ }^{1}$, Livia Khairunisa ${ }^{2}$, Budi Prihatminingtyas ${ }^{3}$ \\ ${ }^{12}$ Prodi Akuntansi Universitas Tribhuwana Tunggadewi \\ ${ }^{3}$ Prodi Manajemen Universitas Tribhuwana Tunggadewi \\ E-mail:whinnyqori678@gmail.com
}

\begin{abstract}
The purpose of this study is to find out how effective game-based learning is for improving Javanese script reading and writing skills. This research method is qualitative with the sources of data from this study are caregivers, foster children, and documents. The target in this study was the Al-Maun orphanage located on Margo Noyo street, Ngajum Village, Ngajum District, Malang Regency, East Java Province, Indonesia. Data collection techniques used were interviews, observation, documentation and tests. The data analysis technique used is an interactive model. From the results of this study it can be concluded that the game-based learning method is very effective in improving the ability to read and write Javanese script among children. Judging from the results the average value of children - children increased and only $8 \%$ are below the average $(<75)$.
\end{abstract}

Keywords: teaching method; game; javanese script.

\begin{abstract}
ABSTRAK
Tujuan dari penelitian ini adalah untuk mengetahui seberapa efektif pembelajaran berbasis game untuk meningkatkan keterampilan membaca dan menulis aksara jawa. Metode penelitian ini adalah kualitatif dengan sumber data dari penelitian ini adalah pengasuh, anak asuh, dan dokumen. Sasaran dalam penelitian ini adalah panti asuhan Al-Maun yang terletak di Jalan Margo Noyo, Desa Ngajum, Kecamatan Ngajum, Kabupaten Malang, Provinsi Jawa Timur, Indonesia Teknik pengumpulan data yang digunakan adalah wawancara, observasi, dokumentasi dan tes. Teknik analisis data yang digunakan adalah model interaktif. Dari hasil penelitian ini dapat disimpulkan bahwa metode pembelajaran berbasis game sangat efektif untuk meningkatkan kemampuan membaca dan menulis aksara Jawa di kalangan anak-anak. Dilihat dari hasilnya rata- rata nilai anak - anak meningkat dan hanya $8 \%$ yang berada dibawah rata - rata $(<75)$.
\end{abstract}

Kata kunci: metode pembelajaran; game; aksara jawa.

\section{PENDAHULUAN}

Masalah yang menjadi perhatian peneliti yaitu kurangnya perhatian pemerintah terhadap budaya jawa. Takano (2011) mengungkapkan bahwa budaya jawa saat ini kurang diperhatikan, baik oleh pemerintah maupun masyarakat Indonesia. Hal ini disebabkan oleh beberapa hal, salah satunya adalah keberadaan teknologi yang semakin canggih, sehingga orang lebih sibuk bermain gadget daripada belajar budaya Indonesia seperti aksara Jawa. Apalagi, orang tua sekarang ingin anak-anak mereka mengikuti era modern. Begitu banyak anak Indonesia, terutama yang asli Jawa saat ini yang tidak mengerti bahkan tidak tahu apa-apa tentang aksara Jawa. Dengan memudarnya budaya Jawa, terutama karakter Jawa di masyarakat,

Cara mengutip: Fatima, W.Q., Khairunisa, L. \& Prihatminingtyas, B. (2020). Metode Pembelajaran Berbasis Game untuk Meningkatkan Ketrampilan Membaca dan Menulis Aksara Jawa. Inteligensi: Jurnal Ilmu Pendidikan, 3(1), 17-22 
karakter Jawa dilupakan atau bahkan hilang. Karena alasan ini, budaya aksara Jawa dewasa ini perlu dipelajari dan dilestarikan. Berdasarkan informasi dari salah satu pengurus Panti Asuhan Al Maun, terdapat satu panti asuhan di desa Ngajum yang saat ini belum memberikan pendidikan tentang aksara Jawa, yaitu Panti Asuhan Al-Maun. Panti Asuhan Al Maun terletak di Jalan Margo Noyo, Desa Ngajum, Kecamatan Ngajum, Kabupaten Malang, Provinsi Jawa Timur, Indonesia. Berdasarkan hasil wawancara yang telah peneliti lakukan, ada beberapa masalah yang menjadi perhatian peneliti adalah kurangnya fasilitas pendidikan, terutama di bidang aksara Jawa. Jadi hal ini menyebabkan kurangnya pengetahuan anak-anak panti asuhan Al-Maun tentang aksara.

Masalah yang dihadapi oleh Panti Asuhan Al-Maun adalah kurangnya staf pengajar, terutama di bidang mata pelajaran aksara Jawa. Jadi ini adalah salah satu masalah di panti asuhan karena tidak ada yang membantu mengisi waktu luang di panti asuhan, padahal literasi bersifat penting karena tidak hanya berkaitan dengan minat baca saja, namun juga terkait dengan literasi tulis (Setiawan, dkk., 2019). Selain itu, pengajaran aksara Jawa di sekolah masih bersifat monoton sehingga anak-anak kurang tertarik untuk mempelajari aksara jawa. Berdasarkan hasil wawancara dengan pengasuh Panti Asuhan Al-Maun, sebagian besar anakanak panti asuhan duduk di sekolah dasar pada kelas 4 dan 5 rata-rata sehingga panti asuhan membutuhkan staf pengajar untuk membantu anak-anak menghadapi ujian di kelas 6 nanti. Pengasuh juga ingin meningkatkan jumlah staf pengajar untuk membantu anak-anak belajar mata pelajaran formal selain di sekolah. Salah satu mata pelajaran yang biasanya diuji di sekolah dasar adalah aksara Jawa. Aksara Jawa di zaman sekarang ini telah sedikit dan berkurang yang mempelajari karena era revolusi industri yang lebih modern.

Tujuan dari penelitian ini adalah untuk mengetahui seberapa efektif pembelajaran berbasis game untuk meningkatkan keterampilan membaca dan menulis aksara jawa. Menurut Slavin (2011). Teams Games Tournament adalah salah satu teknik terbaik dalam pembelajaran. Turnamen Teams Games juga telah dipelajari oleh Veloo \& Chairhany (2013). Penelitiannya menunjukkan bahwa ada pengaruh yang signifikan TGT terhadap prestasi belajar siswa. Penggunaan media yang terinspirasi oleh Roullette juga digunakan dalam penelitian Wulansari \& Durinta (2017) dengan hasil tanggapan kuesioner siswa terhadap media yang dikembangkan menunjukkan hasil persentase $72 \%$ dengan kriteria kelayakan.. Maka dapat disimpulkan bahwa media smart wheel layak digunakan dalam proses pembelajaran.

Berdasarkan hasil penelitian di atas, penulis bermaksud untuk melakukan penelitian berjudul "Metode Pembelajaran Berbasis Game untuk Meningkatkan Keterampilan Membaca \& Menulis Aksara Bahasa Jawa".

\section{METODE PENELITIAN}

Penelitian ini dilaksanakan dari bulan April hingga Agustus 2019. Penelitian ini berlangsung selama kurang lebih 5 bulan dan dilaksanakan di Panti Asuhan Al-Maun yang terletak di Jalan Margo Noyo, Desa Ngajum, Kecamatan Ngajum, Kabupaten Malang, Provinsi 
Jawa Timur, Indonesia. Panti Asuhan Al Maun dihuni oleh pengasuh dan anak yatim dengan jumlah anak yang tinggal di panti asuhan Al-Maun adalah sekitar 18 orang. Tingkat usia bervariasi, dari yang kecil hingga sekolah dasar. Untuk jumlah anak laki-laki yang pernah sekolah dasar adalah 5 orang, untuk jumlah anak perempuan yang pernah sekolah dasar adalah 6 orang. Sedangkan 7 lainnya masih balita. Metode penelitian ini adalah kualitatif. Sumber data dari penelitian ini adalah pengasuh, anak asuh, dan dokumen. Teknik pengumpulan data yang digunakan adalah wawancara, observasi, dokumentasi dan tes. Teknik analisis data yang digunakan adalah model interaktif.

Teknik pelaksanaan pengajarannya adalah dengan menggunakan sosialisasi dan pelatihan aksara Jawa melalui permainan, cerita, film pendidikan, dan kegiatan menarik lainnya untuk membangkitkan minat mempelajari aksara Jawa ini. Urutan pelaksanaan kegiatan pengajaran yang peneliti lakukan:

a) Membeli Peralatan dan Bahan

Sebelum membuat persiapan dalam membuat modul, silabus, dll. Perlu membeli peralatan dan bahan yang dibutuhkan untuk pembuatan.

b) Pembuatan Silabus Pengajaran

Dalam silabus pengajaran ini berisi jadwal mengajar dan materi apa yang telah disampaikan.

c) Membuat Pertanyaan Evaluasi

Pembuatan pertanyaan evaluasi ini bertujuan untuk mengetahui seberapa baik anak-anak memahami materi yang telah disampaikan selama beberapa bulan.

d) Cari Film dan Game Edukasi

Pencarian film dan game edukasi ini menggunakan pencarian di internet. Selain itu, kami juga menyiapkan game edukasi buatan sendiri yaitu TTS aksara Jawa dan mencari kata-kata Jawa.

e) Pengantar Aksara Jawa

Dalam kegiatan ini, kami memberikan pengantar dalam bentuk dasar-dasar aksara Jawa. Kami menggunakan teknik dalam bentuk gambar untuk pengenalan aksara Jawa.

f) Mengajar aksara Jawa

Kegiatan pembelajaran aksara Jawa ini sedikit berbeda dalam tekniknya karena dalam mempelajari aksara Jawa lebih menekankan pada visual dan memori. Jadi kami telah memberi anak-anak mengajar dengan permainan aksara Jawa.

g) Mengajar aksara Jawa melalui permainan

Dalam mengajarkan aksara Jawa, kami menggunakan permainan untuk anakanak. Teknik ini dilakukan agar anak-anak tidak bosan dan lebih antusias dalam mempelajari aksara Jawa. Untuk mengajarkan aksara Jawa, kami lebih menekankan permainan seperti ular dan tangga, teka-teki silang, dan menulis katakata lain.

h) Memahami Tes Evaluasi Materi

Tes evaluasi pemahaman ini dilakukan untuk mengetahui seberapa besar kemampuan anak dalam menguasai materi sebelum pengajaran berbasis game dan setelah pengajaran berbasis game. Tes evaluasi dilakukan dengan 2 cara, yaitu dengan mengadakan Pre-Test dan PostTest.

i) Mengevaluasi Cara Mengajar

Setelah dilakukan kegiatan mengajar kira-kira sebulan sekali, kami melakukan evaluasi sehingga kami bisa mengetahui di mana kendala dan kekurangan kami selama mengajar. Maka dengan evaluasi ini, kita dapat memperbaiki kekurangan kita pada saat mengajar.deskriptif. 


\section{HASIL DAN PEMBAHASAN}

Berdasarkan hasil selama pelaksanaan kegiatan penelitian, diperoleh informasi bahwa pembelajaran karakter Jawa menjadi pelajaran yang cukup menarik. Hasil keterampilan menulis kalimat sederhana aksara Jawa atau PreTest dapat dilihat pada diagram sebagai berikut:

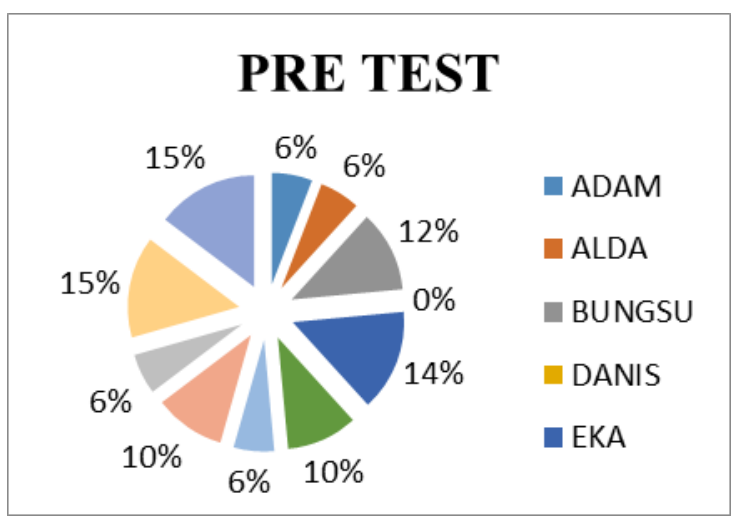

Gambar 1. Diagram Hasil Pre-Test Kognitif

Dari hasil Pre-Test di atas, dinyatakan bahwa dari 11 anak yang terdaftar untuk mengikuti pelatihan dan 10 anak yang mengikuti Pre-Test, masih ada sejumlah anak yang nilainya di bawah rata-rata, hal ini disebabkan karena di panti asuhan ini memang belum ada yang mengajarkan aksara jawa, selain itu pendidikan aksara di sekolah pengajarannya masih bersifat monoton.

Setelah pelatihan selama 10 pertemuan, hasil Post-Test anak-anak membaik dengan sangat baik. Berikut ini adalah diagram hasil Post-Test aksara jawa untuk anak-anak tingkat menengah dengan materi yang telah sampai pada aksara pasangan. Dimana dari hasil Post-test yang dijelaskan pada diagram di atas dinyatakan bahwa mereka yang masih di bawah nilai rata-rata dikurangi menjadi 2 anak dan nilai terendah adalah $8 \%$, tetapi ada anakanak yang tidak mengambil Post-Test sebagai sebanyak 2 anak, seperti yang disajikan pada gambar 2 berikut:

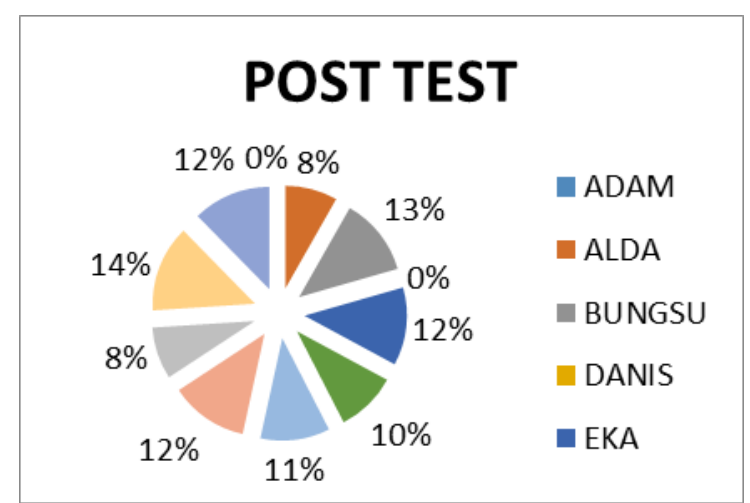

Gambar 2. Diagram Hasil Post-test.

Hasil setelah pelatihan ini sangat memuaskan karena banyak anak yang memahami sistem pembelajaran menggunakan metode permainan edukatif ini, dan pengamatan selama pengajaran banyak anak-anak senang dengan program ini. Metode pembelajaran alfabet Jawa berdasarkan permainan edukatif sangat efektif untuk melatih membaca dan menulis karakter Jawa, karena anak-anak lebih antusias dan cenderung ingin tahu tentang permainan yang disampaikan dan tidak membosankan bahkan ketika membahas materi pelajaran. Puspitasari (2013) Penerapan pembelajaran dengan menggunakan strategi scramble dapat membantu siswa lebih tertarik dalam mengerjakan soal dan melatih siswa dalam membaca huruf aksara Jawa. Isnaini (2012) Penelitiannya menunjukkan bahwa penggunaan strategi scrumble dapat meningkatkan keterampilan menulis karangan pada siswa kelas IV MI Muhammadiyah Beji kecamatan tulung kabupaten klaten tahun pelajaran 2011/2012.

Slavin (2011) menyatakan bahwa Teams Games Tournament adalah bentuk pembelajaran kooperatif yang paling banyak diterapkan dan salah satu teknik 
terbaik dalam pembelajaran, yang telah digunakan dari kelas 2 hingga kelas 11, dalam mata pelajaran mulai dari matematika, seni bahasa, sains sosial, dan ilmu alam. Menurut Slavin (2011). Shoimin (2013: 207) juga menyatakan bahwa keuntungan menggunakan model pembelajaran TGT adalah model pembelajaran TGT, membuat siswa lebih antusias dalam mengikuti pelajaran karena ada kegiatan permainan dalam bentuk turnamen dalam model ini. Avianto (2018) dalam penelitiannya menunjukkan bahwa siswa dapat mengenal dan mempelajari aksara Jawa, serta meningkatkan minat terhadap aksara Jawa itu sendiri. Guru juga dapat melakukan evaluasi terhadap pembelajaran aksara Jawa dengan penggunaan media board game.

Slamet mengatakan bahwa (2014: 105) untuk menjadikan pembelajaran membaca dan menulis menarik bagi siswa, guru perlu menemukan berbagai cara. Salah satu cara yang dapat digunakan guru adalah menggunakan permainan dalam kegiatan belajar. Sehingga dengan penerapan model TGT anak-anak lebih tertarik untuk berpartisipasi dalam pembelajaran. Pentingnya penerapan media dalam proses pembelajaran dikemukakan oleh Arsyad, (2015: 19) yaitu penerapan media dalam proses belajar mengajar dapat membangkitkan keinginan dan minat baru, membangkitkan motivasi dan stimulasi kegiatan belajar, dan bahkan membawa pengaruh psikologis pada anak-anak. Oleh karena itu, dapat disimpulkan bahwa aplikasi media pembelajaran adalah salah satu perantara yang sangat berpengaruh dalam keberhasilan suatu pembelajaran.

Dengan demikian penerapan model pembelajaran media permainan berbasis aksara Jawa mampu meningkatkan konsentrasi dan keaktifan anak-anak yang juga berdampak pada meningkatnya nilai keterampilan menulis dan membaca aksara Jawa.

\section{SIMPULAN}

Berdasarkan hasil penelitian yang dilakukan di Panti Asuhan Al-Maun, dapat disimpulkan, model pembelajaran berbasis aksara Jawa dapat meningkatkan konsentrasi anak dalam belajar. Hal ini dapat dilihat dari keaktifan dan keterlibatan anak dalam proses pembelajaran yang dilihat dari hasil PreTest dan Post-Test. Selain itu, penerapan model pembelajaran aksara Jawa berdasarkan media permainan dapat secara signifikan meningkatkan kemampuan membaca dan menulis aksara Jawa seperti yang terlihat pada diagram hasil Pra-Tes dan Post-Tes. Melalui penerapan model, dapat menciptakan suasana belajar yang menyenangkan dan dapat mengaktifkan anak selama kegiatan belajar.

\section{ACKNOWLEGEMENT}

Dengan selesainya penelitian ini, kami mengucapkan terima kasih kepada Kemenristekditi dalam kegiatan Pekan Ilmiah Mahasiswa tahun pendanaan 2019 dan kami ucapkan terima kasih kepada Bapak Deni Sartika selaku Pengurus Panti Asuhan Al-Maun, Daris Chandra Priatna dan Immanuel atas bantuannya dalam menyelesaikan pelaksanaan penelitian ini

\section{DAFTAR PUSTAKA}

Arsyad, A. 2015. Media Pembelajaran. Jakarta: Rajagrafindo

Avianto, Y. F., \& Tan A. S. P. 2018. Pembelajaran Aksara Jawa untuk Siswa Sekolah Dasar dengan 
Menggunakan Media Board Game. Jurnal Aksara. Universitas Kristen Satya Wacana. Vol. 30, No 1

Isnaini, W. 2012. Peningkatan Keterampilan Menulis Karangan Dengan Penerapan Metode Scrambel Dan Media Gambar Pada Siswa Kelas IV MI Muhammadiyah Beji Kecamatan Tulung Kabupaten Klaten Tahun Pelajaran 2011/2012. Skripsi. Surakarta: FKIP PGSD. Universitas Muhammadiyah Surakarta

Puspitasari. 2020. Pembelajaran Strategi Scrambel.(Online)http://martinapus pitasari.blogspot.com) diakses pada tanggal 06 Mei 2020.

Setiawan, H., Aji, S.M.W., \& Aziz, A. 2019. Puisi Berbasis Karya Gambar: Upaya Penguatan Literasi Siswa SD Kelas Tinggi. Inteligensi: Jurnal Ilmu Pendidikan, 2(1), 50-60.
Shoimin, A. 2016. Model Pembelajaran Inovatif dalam Kurikulum 2013. Yogyakarta: Ar-Ruzz Media.

Slamet. 2014. Pembelajaran Bahasa dan Sastra Indonesia di Kelas Rendah dan Kelas Tinggi Sekolah Dasar. Surakarta: UNS Press

Slavin, R. E. 2011. Cooperative Learning Theory, Research And Practice. USA: Allyn and Bacon A Simon and Schuster Company. $-2^{\text {nd }}$ ed

Veloo, A \& Chairhany, S. 2013.Fostering students'attitude and achievement in probability using Teams Games Tournaments. Procedia-Social and Behavioral Sciences. 93, 2013. 5964.

Wulansari, Y., \& Durinta, P. 2017. PengembanganMedia Pembelajaran Permainan Roda Pintar pada Mata Pelajaran Administrasi Kepegawaian Kelas. Jurnal Administrasi Perkantoran (JPAP). Unesa. Vol 5, No 1 